\title{
Viljelykierron vaikutus vehnän kasvintuhoojien esiintymiseen
}

\author{
Marja Jalli, Erja Huusela-Veistola, Heikki Jalli, Lauri Jauhiainen \\ MTT Kasvintuotannon tutkimus, 31600 Jokioinen, etunimi.sukunimi@mtt.fi
}

\section{Tiivistelmä}

Viljelyn tehostaminen on lisännyt yksipuolista viljelyä. Vaikka viljelykierron edut $\mathrm{mm}$. maan viljavuuden lisääänä ja kasvintuhoojien hillitsijänä tiedostetaan, yksipuolinen vehnän viljely on yleistä Suomessa. Siirtyminen perinteisestä muokkauksesta suorakylvöön muuttaa kasvintuhoojien elinympäristöä. On oletettavaa, että yksipuolisen viljelyn ongelmat korostuvat, kun yksi kasvintuhoojia rajoittava viljelytoimenpide eli muokkaus jää pois.

Viljelykasvien monipuolinen viljely voi vähentää kasvintuhoojien haittavaikutuksia. Viljelykierto on merkittävä osa integroitua kasvinsuojelua, koska se on ympäristöystävällinen ja taloudellinen keino kasvintuhoojien hallintaan. Viljelykierto vaikuttaa isäntävalikoivan kasvintuhoojan esiintymiseen häiritsemällä tuhoojan elinkiertoa. Toisaalta luonnon monimuotoisuus voi toimia myös uusien kasvintuhoojien lähteenä.

Suomessa vehnää vioittavat yleisesti laikkutaudit, tyvitaudit sekä tähkähomeet. Suurin osa viljakasvien lehtilaikkutautien aiheuttajista on isäntävalikoivia, jolloin viljakasvilajeja vuorottelemalla voidaan vaikuttaa lehtilaikkutautien esiintymisen runsauteen. Suorakylvössä viljelykierron merkitys korostuu. Toisaalta suorakylvö voi myös pienentää kasvitautiriskiä ruokkimalla maaperän muita pieneliöitä, jotka kilpailevat taudinaiheuttajien kanssa samasta elintilasta.

Viljelykierron merkitys tuhoeläinten torjunnassa riippuu kahdesta tekijästä: tuhoeläimen liikkumiskyvystä ja sille sopivien ravintokasvien määrästä. Eniten lohkokohtaisesta viljelykierrosta hyötyvät suhteellisen vähän liikkuvat, maassa talvehtivat lajit, joiden ravintokasvivalikoima on suppea. Kun lohkolla viljellään vuorovuosina eri viljelykasvia, tiettyyn viljelykasviin erikoistuneet kasvintuhoojat eivät pääse runsastumaan. Yksipuolisessa vehnän viljelyssä ongelmia aiheuttavat hesseninsääski, tähkäsääski ja vehnäsääski. Viljelykierrosta ei ole apua sellaisten lajien hallinnassa, jotka liikkuvat helposti pitkiä matkoja (kirvat) tai joilla on viljely-ympäristössä paljon isäntäkasveja (kahukärpänen).

Rikkakasvien hallinnassa kasvinvuorotuksen vaikutus on suurinta, kun käytettävissä on mahdollisimman suuri valikoima erilaisia kasveja. Tällöin kasvien kilpailukyky ja mahdolliset torjuntatoimet vaihtelevat vuosittain, eivätkä tiettyihin oloihin sopeutuneet rikkakasvit pääse lisääntymään eikä herbisidiresistenssiä synny.

Tässä työssä esitämme tuloksia Jokioisiin vuonna 2005 perustetusta viljelykiertokokeesta. Kentällä tutkittiin erityyppisten kevätvehnäpohjaisten viljelykiertojen vaikutuksia kasvituhoojien hallintaan suorakylvössä sekä kynnetyllä pellolla. Kevätvehnän lisäksi kierrossa olivat ohra, herne ja rypsi. Viljelykiertokokeen tulokset vuosilta 2005-2011 osoittavat monipuolisen kierron hyödyn sekä muokatussa että muokkaamattomassa kasvualustassa. Sekä kynnettäessä että suorakylvettäessä kevätvehnän keskimääräinen sato oli suurin monipuolisessa viljelykierrossa ja heikoin monokulttuurissa. Kasvukauden olosuhteet vaikuttivat kasvintuhoojien esiintymiin ja myös viljelykierrolla saatuihin vaikutuksiin. Monipuolinen viljelykierto hillitsi erityisesti kevätvehnän pistelaikun esiintymistä.

\section{Asiasanat}

Kevätvehnä, biodiversiteetti, suorakylvö, muokkaus, kasvitaudit, tuhoeläimet, rikkakasvit 


\section{Johdanto}

Kasvintuotannon tulos on useiden biologisten ja teknologisten tekijöiden yhdysvaikutusten summa. Kasvinviljelyssä tuoton maksimointiin pyritään käyttämällä tehokkaasti panoksia (kasvinsuojeluaineet, lannoitteet, vesi) ja uutta teknologiaa. Viljelykasvivalintaa ohjaavat markkinat, tilalla käytettävissä oleva tekniikka sekä viljelylohkojen soveltuvuus eri kasvilajien viljelyyn. Tehokkuuden vastapainona on huoli viljely-ympäristön kestävyyden tilasta: viljelymaan kasvukunnon heikkenemisestä, biodiversiteetin vähentymisestä ja kasvinsuojeluaineiden lisääntyneen käytön ympäristövaikutuksesta. Kasvinsuojeluaineiden käytön vähentäminen on yksi EU:n maatalouspolitiikan keskeisistä tavoitteista. Parlamentti on hyväksynyt direktiivin 2009/128/EC kasvinsuojeluaineiden kestävästä käytöstä. Direktiivin tavoitteena on vähentää kasvinsuojeluaineista aiheutuvia riskejä ihmisen terveydelle ja ympäristölle. Tavoitteen saavuttamisessa avainasemassa on edistää IPM-työkalun (Integrated Pest Management, integroitu kasvinsuojelu) käyttöönottoa. IPM pyrkii terveeseen kasvustoon ja tasapainoiseen peltoekosysteemiin sekä kannustaa käyttämään luontaisia menetelmiä kasvintuhoojien hillitsemiseksi (Vasileiadis ym. 2011).

Viljelykasvien monipuolinen viljely voi vähentää kasvintuhoojien haittavaikutuksia. Viljelykierto on merkittävä osa IPM-viljelyä, koska se on ympäristöystävällinen ja taloudellinen keino kasvintuhoojien hallintaan. Lohkokohtaisen viljelykierron tavoitteena on muokata kasvuympäristöä niin, että se parhaimmin vastaa eri kasvilajien onnistuneen sadontuotannon vaatimuksiin (Klein Haneveld \& Stegeman 2005). Viljelykierto vaikuttaa isäntävalikoivien kasvintuhoojien esiintymiseen häiritsemällä tuhoojan elinkiertoa. Kasvintuhoojien hallinta perustuu ennaltaehkäisyyn, jossa viljelykierrolla pyritään luomaan epäsuotuisat olosuhteet tuhon aiheuttajalle ja suosiolliset olosuhteet viljelykasville. Toisaalta viljelyn monimuotoisuus voi toimia myös uusien kasvintuhoojien lähteenä (Keesing ym. 2010).

Peltokasvien viljelyssä yleistyneen suorakylvön tavoitteena on säästää viljelytoimissa käytettävää energiaa, parantaa maan viljelykuntoa, vähentää eroosiota ja edistää tuotannon kestävyyttä. Maan muokkaamattomuus vaikuttaa myös viljelykasville haitallisten pieneliöiden, hyönteisten ja rikkakasvien elinympäristöön. Siirtyminen uuteen viljelymenetelmään voi aiheuttaa muutoksia kasvintuhoojalajistossa, lajien esiintymisrunsaudessa ja perimässä (Paulitz 2006). Suorakylvö ei menetelmänä kuitenkaan lisää isäntäkasvispesifisten taudinaiheuttajien ja hyönteisten määrää. Näiden runsastuminen ilmenee vasta vuorovaikutuksesta alttiin isäntäkasvin ja suosiollisten ilmasto-olosuhteiden kanssa.

Suomessa vehnää vioittavat yleisesti laikkutaudit, tyvitaudit sekä tähkähomeet. Suurin osa viljakasvien lehtilaikkutautien aiheuttajista on isäntävalikoivia, jolloin viljakasvilajeja vuorottelemalla voidaan vaikuttaa lehtilaikkutilanteeseen. Tyvi- ja tähkähomeiden aiheuttajista useat ovat moniisäntäisiä, jolloin viljoihin ja nurmiheiniin perustuva viljelykierto ei riitä. Suorakylvössä viljelykierron merkitys korostuu. Toisaalta suorakylvö voi myös pienentää kasvitautiriskiä ruokkimalla maaperän muita pieneliöitä, jotka kilpailevat taudinaiheuttajien kanssa samasta elintilasta. Koska taudinaiheuttajien elinkierto ja eri olosuhteissa selviytyminen vaihtelevat, myös eri viljelykiertojen ja muokkausmenetelmien vaikutukset ovat erilaisia eri taudinaiheuttajilla. Vaikutusten kirjoa lisäävät eri maalajit ja sääolosuhteet (Janusauskaite 2010). Yksipuolisen vehnänviljelyn, alttiiden kasvilajikkeiden sekä suorakylvön on todettu lisänneen vehnän pistelaikun (Pyrenophora tritici-repentis) merkitystä vehnän kasvintuhoojana (Jørgensen \& Olsen 2007). Viljelykiertojen vaikutusta tyvitautien esiintymiseen on tutkittu paljon. Viljelykasvien lisäksi tärkeä tekijä tyvitautien ilmenemiseen ovat lohkolla esiintyvät rikkakasvit (Curl 1963).

Viljelykierron merkitys tuhoeläinten torjunnassa riippuu kahdesta tekijästä: tuhoeläimen liikkumiskyvystä ja sille sopivien ravintokasvien määästä. Lohkokohtaisesta viljelykierrosta on eniten apua sellaisten tuhoeläinlajien hallinnassa, jotka liikkuvat suhteellisen lyhyitä matkoja ja joiden ravintokasvivalikoima on suppea (Coaker 1987). Kun lohkolla viljellään vuorovuosina eri viljelykasvia, tiettyyn viljelykasviin erikoistuneet kasvintuhoojat eivät pääse runsastumaan. Muokkauksen merkitys kasvintuhoojien hillitsijänä puolestaan korostuu lajeilla, jotka talvehtivat maassa tai sängessä.

Mertens ym. (2002) mukaan viljelykiertoa, jossa viljellään tiettyjä kasveja määrätyssä järjestyksessä, pidetään tärkeänä rikkakasvien säätelymenetelmänä. Kevätviljakierrossa voivat 
rikkakasvit suorakylväessä vähentyä, kun rikkakasvien torjuntaa tarkentaa (Legere ym. 1997; Young ym. 2004). Suorakylvämällä ja sopivalla viljelykierrolla on voitu pienentää rikkakasvientorjuntakustannuksia 50 \% (Andesson 2008). Liebmah \& Dyck (1993) tutkimuksen mukaan 21 tapauksessa viljelykierron tuloksena oli vähemmän taimettuneita rikkakasveja kuin monokulttuurissa, kerran enemmän ja viidessä tapauksessa monokulttuurissa taimettui vähemmän rikkakasveja kuin viljelykierrossa.

Monisopu-hankkeessa toteutetun tutkimuksemme tavoitteena oli selvittää viljelykierron mahdollisuuksia kevätvehnän kasvitautien, rikkakasvien ja tuhohyönteisten hallinnassa. Lisäksi selvitimme, onko viljelykierron vaikutus kasvintuhoojien esiintymiseen samanlaista muokatussa ja muokkaamattomassa viljely-ympäristössä.

\section{Aineisto ja menetelmät}

Viljelykierron vaikutusta kevätvehnän kasvintuhoojiin tutkittiin kenttäkokeessa Jokioisilla vuosina 2005-2011. Mukana oli kahdeksan koejäsentä, joista kukin oli sekä muokatussa (syyskyntö) että muokkaamattomassa ympäristössä (Kuva 1). Koejäsenet olivat: 1: kevätvehnän monokulttuuri; 2-5: kevätvehnä joka toinen vuosi, välivuosina ohra ja rypsi; 6-8: kevätvehnä joka neljäs vuosi, välivuosina rypsi, ohra ja herne. Kevätvehnälajikkeena oli Kruunu, ohralajikkeena Annabell, rypsilajikkeena Hohto/Apollo ja hernelajikkeena Hulda. Kokeessa käytettiin sertifioitua ja peitattua kylvösiementä. Rikkakasvi- ja tuhoeläintorjunta tehtiin tarpeen mukaan (Kuva 2). Kasvukaudella ei tehty kemiallista kasvitautien torjuntaa.

Kylvöaika määräytyi sääolosuhteiden mukaan. Tavoitteena oli kylvää muokkaamattomat ja muokatut ruudut mahdollisimman samanaikaisesti huomioiden kylvöalustan kunto. Kevätvehnän lannoitustaso oli $110 \mathrm{~kg} \mathrm{~N} /$ ha. Herneen ollessa esikasvina kevätvehnän lannoitustaso oli $80 \mathrm{~kg} \mathrm{~N} / \mathrm{ha}$.

\begin{tabular}{|c|c|c|c|c|c|c|c|c|c|}
\hline KOEJÄSEN & 2003 & 2004 & 2005 & 2006 & 2007 & 2008 & 2009 & 2010 & 2011 \\
\hline 1 & vehnä & vehnä & vehnä & vehnä & vehnä & vehnä & vehnä & vehnä & vehnä \\
\hline 2 & vehnä & rypsi & vehnä & ohra & vehnä & rypsi & vehnä & ohra & vehnä \\
\hline 3 & vehnä & vehnä & rypsi & vehnä & ohra & vehnä & rypsi & vehnä & ohra \\
\hline 4 & vehnä & ohra & vehnä & rypsi & vehnä & ohra & vehnä & rypsi & vehnä \\
\hline 5 & vehnä & vehnä & ohra & vehnä & rypsi & vehnä & ohra & vehnä & rypsi \\
\hline 6 & vehnä & vehnä & rypsi & ohra & herne & vehnä & rypsi & ohra & herne \\
\hline 7 & vehnä & rypsi & ohra & herne & vehnä & rypsi & ohra & herne & vehnä \\
\hline 8 & vehnä & ohra & herne & vehnä & rypsi & ohra & herne & vehnä & rypsi \\
\hline
\end{tabular}

Kuva 1. Kevätvehnän viljelykiertokokeen koejärjestely. Kaikki koejäsenet olivat sekä muokatussa että muokkaamattomassa ympäristössä.

\section{Tulokset ja tulosten tarkastelu}

Kevätvehnän sadoissa esiintyi suuria vuosittaisia vaihteluja. Keskimäärin kevätvehnän sato oli samansuuruinen sekä kynnettäessä että suorakylvettäessä. Suorakylvetyt kasvustot kärsivät vähemmän alkukasvukauden kuivuudesta. Kynnettyyn maahan kylvetty kevätvehnä pärjäsi puolestaan paremmin kosteina kasvukausina. Sekä kynnettäessä että suorakylvettäessä kevätvehnän keskimääräinen sato oli suurin monipuolisessa viljelykierrossa ja heikoin monokulttuurissa. Monipuolisen viljelykierron positiivinen vaikutus heijastui myös tuhannen siemenen painoon. 


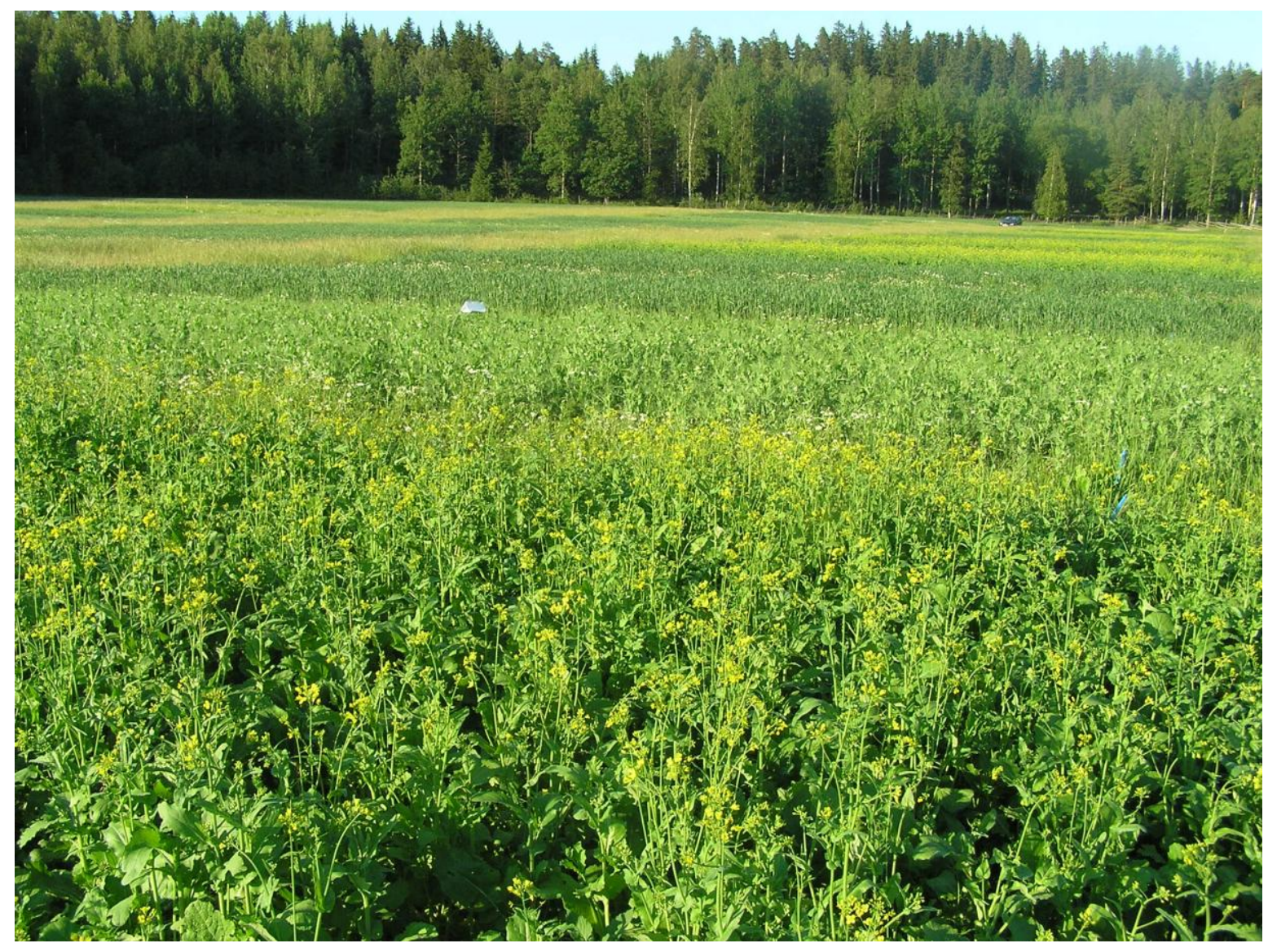

Kuva 2. Jokioisten viljelykiertokeen ruutukoko on $6 \times 15 \mathrm{~m}^{2}$. Hernekasvustossa näkyy feromonipyydys, jolla seurattiin hernekääriäisten esiintymistä ja arvioitiin torjuntatarvetta. (Kuva Marja Jalli).

\section{Kasvitaudit}

Viljelykiertokokeessa tutkittiin viljelykierron vaikutusta kevätvehnässä esiintyviin kasvitauteihin. Tyvi- ja lehtilaikkutautien vioituksen voimakkuus havainnoitiin korrenkasvun alussa sekä maitotuleentumisvaiheessa. Tyvitaudinaiheuttajat määritettiin maljaamalla tyvet ravintoalustalle.

Vehnän laikkutautien vioitus oli suurin monokulttuurissa. Lehtilaikkutaudeista oli yleisin pistelaikku (Pyrenophora tritici-repentis). Erot olivat suurimmat korrenkasvun alussa ja tasoittuivat kasvukauden edetessä. Etenemiseen vaikuttivat merkitsevästi kasvukauden sääolosuhteet. Viljelykierron vaikutus kevätvehnän tyvitautivioitukseen oli erilainen kynnössä ja suorakylvössä. Muokatussa ympäristössä viljelykierto ei vaikuttanut oireiden voimakkuuteen. Suorakylvettäessä oireet olivat voimakkaimmat monokulttuurissa ja pienimmät monipuolisimmassa viljelykierrossa. Monipuolisessa viljelykierrossa, jossa vehnä on joka neljäs vuosi, tyvitautivioitusten määrä oli yhtä suuri kynnettäessä ja suorakylvettäessä.

Vehnän pistelaikun merkitys Suomessa on lisääntynyt. Taudinaiheuttajakartoituksen mukaan pistelaikun taudinaiheuttajaa esiintyy yli 90 \%:lla pelloistamme (Jalli ym. 2011). Merkittävin pistelaikun tartuntalähde on edellisen kasvukauden kasvijäte, jolloin viljelykierrolla on suurin merkitys sen torjunnassa. Viljelykiertokoe selkeytti eron esikasvin ja viljelykierron välillä pistelaikun hallinnassa. Yhden vuoden tauko ei voimakkaan pistelaikkuvuoden jälkeen ollut riittävä taudinaiheuttajan vähentämiseksi. Kun vehnää viljeltiin joka toinen vuosi, ei pistelaikun esiintymisen kannalta ollut merkittävää, onko esikasvina ohra vai rypsi. Vaikka $P$. tritici-repentis on vehnän patogeeni, se tartuttaa myös muita viljakasveja (Kuva 3). Pelkkä viljapohjainen viljelykierto ei riitä sen hallintaan vaan mukana on oltava öljy- ja palkokasveja (Duczek ym. 1999). Viljelykierron vaikutukset pistelaikun esiintymiseen olivat samansuuntaiset muokatussa ja muokkaamattomassa ympäristössä. Muokkaamattomassa ympäristössä erot eri koejäsenten välillä olivat suurimmat 
kasvukauden alussa. Tämä tukee käsitystä kasvijätteen merkityksestä pistelaikun elinkierrossa (Krupinsky ym. 2004).

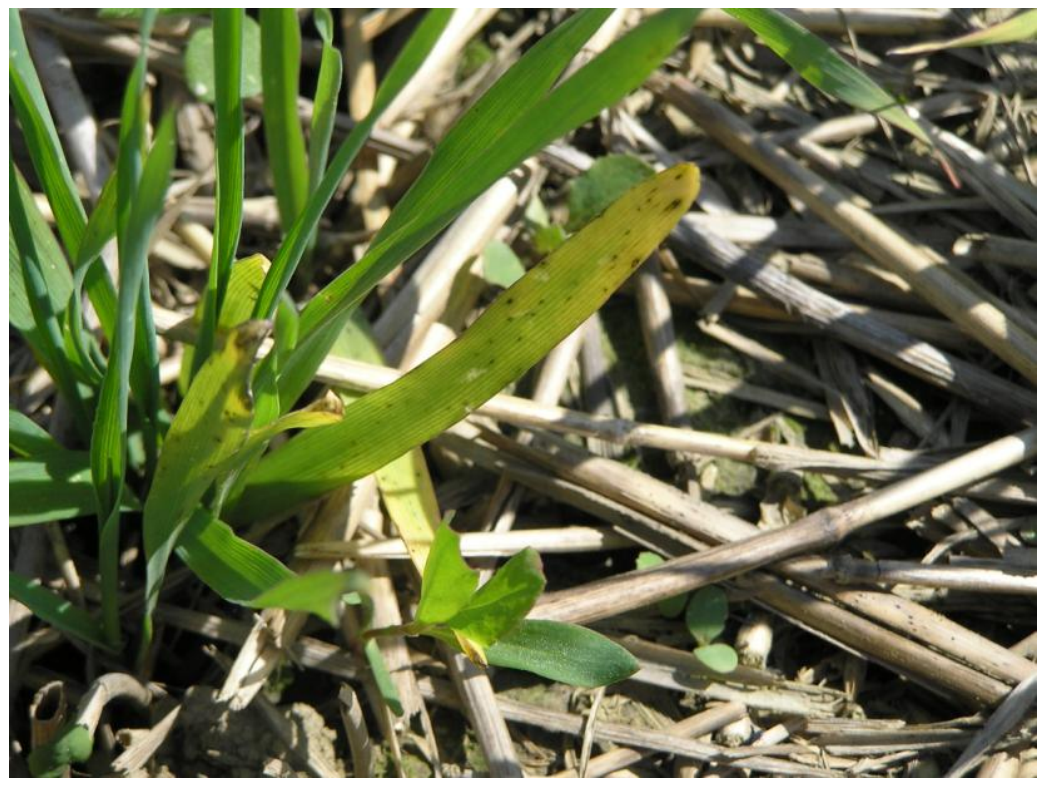

Kuva 3. Viljelykiertokokeessa pistelaikku tartutti myös ohraa. Oireet näkyivät pieninä tummina pisteinä, jotka eivät laajentuneet kasvukauden edetessä. (Kuva Marja Jalli).

Tyvitautien määrä pysyi viljelykiertokokeessa alhaisella tasolla. Vehnälle haitallista mustatyveä ei kokeessa esiintynyt lainkaan. Tyvitauteja aiheuttivat lähinnä Fusarium culmorun ja Fusarium avenaceum -lajit. Seitsemän vuoden jakso ei välttämättä ole riittävä kuvaamaan sitä muutosta, jonka eri viljelykierrot saavat aikaan maaperän mikrobistossa. Monipuolisen viljelykierron tyvitaudinoireita vähentävä vaikutus suorakylvettäessä kertoo kuitenkin mikrobilajiston kehityksen suunnan: maan supressiivisuus maan pintakerroksissa lisääntyi. Yksittäisten lajien runsauteen viljelykierrot vaikuttivat eri tavoin. Esimerkiksi Fusarium culmorum -sienen esiintymiseen vaikutukset olivat vastakkaiset muokatussa ja muokkaamattomassa ympäristössä. Tyvitauteja vastaan ei juurikaan esiinny taudinkestävyyttä. Myös kemiallisen torjunnan mahdollisuudet ovat hyvin rajalliset. Tyvitautien torjunnassa korostuu viljelykierron ja muokkausmenetelmien sekä niiden yhdysvaikutuksen merkitys. Tehokas rikkakasvien torjunta ja olkijätteen käsittely vähentävät kasvitautiriskiä (Paulitz 2006).

\section{Tuhoeläimet}

Yksipuolisessa vehnän viljelyssä ongelmia aiheuttavat hesseninsääski Mayetiola destructor, tähkäsääski Sitodiplosis mosellana ja vehnäsääski Contarinia tritici. Näiden lajien torjunnassa viljelykierron monipuolistaminen on yksi keino (Glen 2000). Viljelykierrosta ei ole yleensä apua sellaisten lajien hallinnassa, jotka liikkuvat helposti pitkiä matkoja, kuteen tuomikirva Rhopalosiphum padi, tai joilla on viljely-ympäristössä paljon isäntäkasveja, esim. kahukärpänen.

Jokioisten viljelykiertokokeen vehnäkasvustoissa tuhoeläinvioitusten määrä oli melko pieni vuosina 2005-2011, eikä tuhoeläinten torjuntaan ole ollut tarvetta. Viljelykierron ja muokkauksen vaikutusta tuhoeläimiin on tutkittu vuosittain laskemalla kahukärpäsen vioitukset versomisvaiheessa ja tähkäsääsken vioittamia jyvät maitotuleentumisvaiheessa otetuista vehnänäytteistä. Erilaisten viljelykiertojen välillä ei havaittu tilastollista eroa, mutta viljelykierron ja muokkauksen yhdysvaikutus kahukärpäsvioituksen määrään oli merkitsevä $(\mathrm{P}<0,05)$. Yhdysvaikutus johtui siitä, että monipuolisen viljelykierron kahukärpäsvioitusten määrää vähentävä vaikutus tuli esille vain suorakylvössä. Tähkäsääsken vioittamien jyvien määrissä ei eroa eri viljelykiertojen välillä havaittu. On huomioitava, että koejärjestelyn mittakaava ei ole riittävä viljelykierron vaikutusten mittaamiseen tuhohyönteisillä, jotka helposti voivat siirtyä koeruudusta toiseen. 
Viljelykierron merkitys tuhoeläinten hallinnassa on selvästi rajallisempi kuin kasvitautien hallinnassa. Tuhoeläinten hallintaan vaikuttavat myös tietyn viljelykasvin viljelyn laajuus ja lohkojen etäisyys toisistaan. Monen tuholaislajin kohdalla lohkokohtaisen viljelykiertoa tärkeämpi on alueellinen viljelykierto, "area-wide pest management" (Sexon \& Wyman 2005, Huusela-Veistola \& Jauhiainen 2006).

\section{Rikkakasvit}

Hankkeessa tutkittiin viljelykierron vaikutusta vehnän rikkakasvilajistoon ja eri lajien runsauteen. Rikkakasvihavainnot tehtiin ennen herbisidikäsittelyä. Rikkakasvit laskettiin lajeittain vuosina 20052007 kuudesta kohtaa koeruudulta $0,1 \mathrm{~m}^{2}: \mathrm{n}$ alalta ja vuosina 2008-2011 viidestä kohtaa. Viljoilta rikkakasvit torjuttiin vuosittain Ariane $S$-valmisteella, jonka käyttömäärä oli 1,7 1/ha. Herneellä käytettiin taimettumisen jälkeen Fenix-valmistetta. Rypsin rikkakasvit torjuttiin muokatuilta ruuduilta ennen kylvöä Triflural- tai Devrinol-herbisideillä. Heinämäisten rikkakasvien lisääntyminen suorakylvöruuduilla estettiin syyskuun lopussa tehdyin glyfosaattikäsittelyin vuosina 2009 ja 2010.

Monokultturin vehnäruuduilla oli rikkakasveja keskimäärin yli vuosien kynnettäessä $160 \mathrm{kpl} / \mathrm{m}^{2}$ ja suorakylvettäessä $115 \mathrm{kpl} / \mathrm{m}^{2}$. Kynnettäessä vain kierto- ja pihatatarta kasvoi enemmän kuin suorakylvettäessä. Suorakylvöksellä viihtyivät peltomatara, pihatähtimö, saunakukka ja heinämäiset rikkakasvit, sekä linnunkaali, peltoemäkki ja peltolemmikki, joita kasvoi pellolla vähän. Muokkauksella tai muokkaamattomuudella ei ollut vaikutusta peipin, jauhosavikan, pillikkeen tai peltotaskuruohon esiintymiseen. Näiden määrä pellolla oli vähäinen.

Viljelykierron monipuolistaminen lisäsi kevätvehnällä ennen kemiallista torjuntaa taimettuneiden rikkakasvien määrää etenkin suorakylvettäessä. Toisenlaisen tuloksen saivat Arshad ym. (1998), joiden mukaan viljelykieron vaikutus rikkakasvillisuuteen on sama maata muokattaessa ja suorakylvettäessä. Rikkakasvien määrän lisääntyminen siirryttäessä monokulttuurista viljelykiertoon johtunee etenkin kierrossa olleen rypsin rikkakasvitorjunnan vaikeuksista. Myös herneen rikkakasvin torjunnan rajallisuus antaa mahdollisuuden rikkakasvien lisääntymiselle. Heikko rikkakasvien torjuntatulos realisoituu suorakylvettäessä syksyllä taimettuvina ja talvehtivina rikkakasveina tai vasta keväällä itävinä siemeninä.

Viljeltäessä vehnän monokulttuuria rikkakasvit vähenevät tehokkaan kemiallisen torjunnan takia. Kynnettäessä monokulttuurissa yleisimmiksi rikkakasveiksi kokeessa muotoutuivat punapeippi, pihatähtimö ja peltoemäkki. Kevätvehnää, ohraa ja rypsiä sisältävässä kierrossa oli kynnettäessä yleisenä rikkakasvina lisäksi matara. Samat rikkakasvit olivat yleisiä lisättäessä herne viljelykiertoon. Suorakylvettäessä monokulttuurissa kasvoi yleisimpänä heinämäsiet rikkakasvit, peltomatara ja punapeippi. Monipuolisessa viljelykierrossa lajisto kasvoi pihatähtimöllä ja saunakukalla.

\section{Johtopäätökset}

Viljelykierto on osa integroitua torjuntaa. Integroidussa torjunnassa hyödynnetään ne tekijät, jotka vähentävät tai vaikeuttavat tietyn kasvintuhoojan menestymistä vaikuttamalla sen isäntäkasvin paikantamiseen, kolonisaatioon, lisääntymiseen, elossasäilymiseen ja leviämiseen. Viljelykierto toimii kasvintuhoojia ennaltaehkäisevästi. Monipuolinen viljely vähentää kasvintuhoojariskejä, jotka ilmenevät eri tavoin eri muokkausmenetelmissä ja ympäristöolosuhteissa. Optimaalinen viljelykierron pituus ja kasvilajien määrä vaihtelee eri kasvintuhoojilla. Parhaimmillaan viljelykierrossa ei ole välikasveja vaan jokaisen kasvilajin viljelyyn panostetaan, ja kasvitautien, tuhohyönteisten sekä rikkakasvien torjunnasta huolehditaan. Viljelyn monimuotoisuus voi tuoda mukanaan muita kasvinsuojeluongelmia. Myös ilmaston muuttuminen saattaa muuttaa eri kasvintuhoojien merkitystä. Sopivan viljelykierron valinnassa tuleekin painottaa todennäköisempien tai ongelmallisten kasvintuhoojien torjuntaa. 


\section{Kirjallisuus}

Andersson, R.L. 2008. Diversity and No-Till: Keys for Pest Management in U.S. Great Plains. Weed science 56:141-145.

Arshad, M.A, Gill, K.S \& Izaurralde, R.C. 1998. Wheat production, weed population and soil properties subsequent 20 years of sod as affected by crop rotation and tillage. Journal of sustainable agriculture 12: 2-154.

Coaker, T.H. 1987. Cultural methods: The crop. Teoksessa: Burn, A. J., Coaker, T.H. \& Jepson, P.C. (toim.) Integrated Pest Management. Academic Press, London s. 69-88.

Curl, E.A. 1963. Control of plant diseases by crop rotation. Botanical Review 29: 413-479.

Duczec, L.J., Sutherland, K.A., Reed, K.L., Bailey, K.L. \& Lafond, G.P. 1999. Survival of leaf spot pathogens on crop residues of wheat and barley in Saskatchewan. Canadian Journal of Plant Pathology 21: 165173.

Glen, D.M. 2000. The effects of cultural measures on cereal pests and their role in integrated pest management. Integrated Pest Management Reviews 5: 25-40.

Huusela-Veistola, E., \& Jauhainen, L. 2006. Expansion of pea cropping increases the risk of pea moth (Cydia nigricana; Lep., Tortricidae) infestation. Journal of Applied Entomology 130:142-149.

Jalli, M., Laitinen, P., Latvala, S. 2011. The emergence of cereal fungal diseases and the incidence of leaf spot diseases in Finland. Agricultural and Food Science 20, 1: 62-73.

Jørgensen, L.N. \& Olsen, L.V. 2007. Control of tan spot (Drechslera tritici-repentis) using cultivar resistance, tillage methods and fungicides. Plant Protection 26:1606-1616.

Janusauskaite, D \& Ciuberkis, S. 2010. Effect of different soiul tillage and organic fertilizers on winter triticale and spring barley stem base diseases. Crop protection 29: 802-807.

Keesing, F., Belden, L.K., Daszac, P., Dobson, A., Harvell, D., Holt, R.D., Hudson, P., Jolles, A., Jones, K.E., Mitchell, C.E., Myers, S.S., Bogich, T. \& Ostfeld, R.S. 2010. Impacts of biodiversity on the emergence and transmission of infectious diseases. Nature 468: 647-652.

Klein Haneveld, W.K. \& Stegeman, A.W. 2005. Crop succession requirements in agricultural production planning. European Journal of Operational Research 2005: 406-429.

Krupinsky, J.M., Tanaka, D.L., Lares, M.T. \& Merril, S.D. 2004. leaf spot diseases of barley and spring wheat as influenced by preceding crops. Agronomy Journal 96: 259-266.

Legere, A. \& Samson, N. 1999. Relative influence of crop rotation, tillage and weed management on weed associations in spring barley cropping systems. Weed science 47: 112-122.

Legere, A. \& Samson, N. 2004. Tillage and weed management effects on weeds in barley-red clover cropping systems. Weed science. 52: 881-885.

Legere, A., Samson, N., Rioux, R., Angers, D. A. \& Simard, R.R. 1997. Response of barley to crop rotation, conservation tillage, and weed management in intensity. Agronomy Journal 89: 268-638.

Liebman, M. \& Dyck, E. 1993. Crop Rotation and Intercropping Strategies for Weed Management. Ecological Applications 3:92-122.

Mertens, S. K., van den Bosch, F \& Heesterbeek, J.A.P. 2002. Weed Populations and Crop Rotations: Exploring Dynamics of a Structured periodic System. Ecological Applications 12:1142-1162.

Paulitz, T.C. 2006. Low input no-till production in the Pacific Northwest of the U.S.: the challenges of root diseases. European Journal of Plant Pathology 115: 271-281.

Sexon, D.L. \& Wyman, J.A. 2005. Effect of crop rotation distance in populations of Colorado potato beetle (Coleoptera: Chrysomelidae): Development of area wide Colorado potato beetle pest management strategies. Journal of Economic Entomology 98: 716-724.

Vasileiadis, V.P., Sattin, M., Otto, S., Veres, A., Pálinkás, Z., Ban, R., Pons, X., Kudsk, P., van der Weide, R., Czembor, E., Moonen, A.C. \& Kiss, J. 2011. Crop protection in European maize-based cropping systems: Current practices and recommendations for innovative Integrated Pest Management. Agricultural Systems 104: 533-540.

Young, F.L. \& Thorne, M.E. 2004. Weed species dynamics and management in no-till and reduced-till fallow cropping systems for the semi-arid agricultural region of Pacific Noethwest, USA. Crop protection 23: 1097 1110 . 